\title{
Editorial
}

\section{Award-Winning Research in 2016}

\author{
Geraldo Pereira Jotz ${ }^{1}$ Aline Gomes Bittencourt ${ }^{2}$ \\ ${ }^{1}$ Department of Morphological Sciences, Universidade Federal do Rio \\ Grande do Sul, Porto Alegre, RS, Brazil \\ 2 Universidade Federal do Maranhão, São Luís, MA, Brazil
}

Int Arch Otorhinolaryngol 2016;20:93.

Dear Colleague,

In 2016, the International Archives of Otorhinolaryngology has awarded the two best systematic and/or literature reviews published in our journal in 2015, seeking to highlight articles that form the foundations and concepts of universal knowledge. We believe this serves to identify, evaluate, and interpret all available and relevant studies for a specific thematic issue. The objective is to review the state of the art, confronting the existing evidence on a given subject, and thus seeking new lines of research.

Systematic reviews with meta-analyses used globally by the medical community allow us to ensure that we have as precise a summary as possible, of all the trials that took place on a particular medical science topic.

With this effort, we wish to appreciate and honor awarded authors, encouraging new talents in international otorhinolaryngological research with a commitment to stimulate education and technological development through research and training.

The studies that stood out were the following:

1. Predictors of Success in the Treatment of Obstructive Sleep Apnea Syndrome with Mandibular Repositioning Appliance: A Systematic Review Fernanda Saffer, José Faibes Lubianca Neto, Cassiano Rösing, Caroline Dias, Luciane Closs

Int Arch Otorhinolaryngol. 2015 Jan;19(1):80-5.

2. Tinnitus Neural Mechanisms and Structural Changes in the Brain: The Contribution of Neuroimaging Research Patricia Simonetti, Jeanne Oiticica Int Arch Otorhinolaryngol. 2015 Jul;19(3):259-65.

We hope to review them in future publications. Best wishes,

\section{Geraldo Pereira Jotz} Editor-in-Chief

Aline Gomes Bittencourt

Co-Editor
Address for correspondence Geraldo Pereira Jotz, MD, PhD, Department of Morphological Sciences, Universidade Federal do Rio Grande do Sul, Porto Alegre, RS, Brazil (e-mail: geraldo.jotz@terra.com.br).
DOI http://dx.doi.org/ 10.1055/s-0036-1582428. ISSN $1809-9777$.
Copyright $@ 2016$ by Thieme Publicações License terms Ltda, Rio de Janeiro, Brazil 